\title{
Analysis of Teff Value Chain in Bacho and Dawo Districts of South West Shewa, Ethiopia
}

\author{
Efa Gobena Tura ${ }^{a^{*}}$, Dr. Degye Goshu ${ }^{b}$, Tinsae Demisiec, Tadesse Kenea ${ }^{\mathrm{d}}$
}

aDepartment of Agribusiness and Value Chain Management, Ambo University, Ambo, Ethiopia

${ }^{b}$ School of Agricultural Economics and Agribusiness, Haramaya University, Haramaya University, Ethiopia

'Department of Agricultural Economics and Extension, Jimma University, Jimma, Ethiopia

dDivision of Logistics, Department of Energy and Technology, Swedish University of Agricultural Sciences, Uppsala, Sweden

efagobena@gmail.com

Abstract: This study investigates the value chain of teff in Becho and Dawo district where the livelihood of farmers depend on the production and marketing of teff. The study was particularly designed for identifying and categorizing the value chain actors, evaluate their roles, value added by value chain actors and relationships in the value chain. Multi-stage sampling procedure was employed to draw sample of 150 teff producers. About 54 traders including urban wholesalers, rural wholesalers, urban retailers and rural retailers, consumers, cooperatives, hotels and restaurants, injera sellers, flour sellers, unions and NGOs were also included in the study. The value chain analysis approach developed by GTZ, (2007) was used for financial analysis to capture the share of value added by each value chain participant. Teff farmers received higher returns when they sell their outputs directly to rural wholesalers. The findings show that injera sellers added the largest value to teff. Teff value chain upgrading activity performed by teff farmers includes use of improved seed and differentiates the product by color to meet the consumer demand. Price and standard of teff in the study areas is entirely determined by teff traders. Teff farmers' production and marketing constraints were double taxation, shortage of fertilizer and seed supply, price setting and access to credit whereas that of teff traders were double taxation, absence of infrastructure, capital shortage, access to credit, farmer reluctance to sell, lack of demand, absence of storage facility and absence of government support. The findings generally suggest the need to create trust among value chain actors, strong extension intervention on upgrading the value chain, and giving training for farmers on upgrading value chain through different system.

Keywords: Value chain, teff, value addition

\section{INTRODUCTION}

Value-added agriculture has attracted considerable attention in recent years as a means to increase and/or stabilize farm incomes and to rejuvenate primary agriculture and the rural economy. The move to value-added agriculture is fundamentally market-driven. Value-added activities are born from the necessity to adapt to the wide-ranging changes affecting the agriculture and agro-food industry. These changes stem from many interacting factors; the quick expansion of agricultural trade and the resulting concentration in the agro-food industry, an increasingly segmented consumer base, shifting consumer preferences, changing demographics and income profiles, innovation in food and non-food uses of agricultural products and trade-related issues (Lambert et al., 2006).

Modernization of agricultural value chain systems by which food flows from the farm gate to the consumer is both a consequence and cause of economic development. Commercial demand increases due to income and population growth, urbanization, and trade liberalization. Marketed supply simultaneously rises due 
to productivity improvements in production, post-harvest processing, and distribution systems (Minten and Reardon, 2008). The combination of increased commercial demand and supply induces the emergence of modern marketing channels employing sophisticated management methods, such as costly grades and standards or vertical coordination or integration of activities that profitably add value to raw commodities through transport, storage and/or processing. Farmers whose comparative advantage allows them to tap the latent demand of better-off or more distant markets made accessible by emergent agricultural value chains (AVCs) typically improve their productivity and profitability, thereby further stimulating commercial demand and supply through reinforcing feedback. The emergence and modernization of AVCs thus result from and contribute to economic development (Reardon and Timmer, 2007).

The scientific name of teff is Eragrostistef (Zucc.) and is believed to have originated in Ethiopia (Vavilov, 1951). Teff is a tiny, round, khaki-colored grain closely resembling millet. "Teffa", the Amharic word for "lost", is so named because of teff small size. It is the smallest grain in the world and often is lost in the harvesting and threshing process because of its size. From teff the preferred staple diet made in the Ethiopian and Eritrean is injera (pronounced en-ger- $a$, and sometimes spelled injera), a flat sour-like fermented pancake that is used with "wot", a stew made with spices, meats and pulses, such as lentils, beans and split peas (Piccinin, 2002).

Teff is one of the most important crops for farm income and food security in Ethiopia. Teff accounts for the largest share of the cultivated area (28.5\%) in 2013, followed by maize $(20.3 \%)$ and the second in terms of quantity of production. However, because its market price is often two or three times higher than maize, teff accounts for the largest share of the total value of cereal production. Since teff farm operations such as land preparation, weeding and harvesting are highly labor-intensive, with limited availability of suitable mechanical technology, there are no large-scale teff farmers in the country. It is Ethiopia's most important crop by area planted and value of production, and the second most important cash crop (after coffee), generating almost 464 million USD income per year for local farmers. In the major agricultural season of 2012/13, teff was grown by 6.3 million farm households in Ethiopia. Commercial surplus of teff is equal to the commercial surplus of the three other main cereals combined in the country (sorghum, maize, and wheat (CSA, 2013).

Many farmers grow teff as a cash crop because of its high market price. Teff production expanded by 72 percent between 2004/05 and 2010/11, this growth was achieved mainly due to 29 percent expansion in an area under cultivation and 33 percent increase in yield levels. The share of teff in total cultivated areas increased by 2 percent, compared to the decline in barely ( 25 percent) and wheat (12 percent), and rapid expansion in coarse grains (maize, 11 percent, and sorghum, 19 percent). With only 1.3 tons per hectare, teff yield is the lowest among cereal crops. This is mainly due to limited use of improved seeds, inefficient agronomic practices and fragmented farm plots (MAFAP, 2013).

Urban households more readily eat Teff than rural households (Minten et al., 2013). Berhane et al. (2011) showed, relying on national household consumption data, urban consumption per capita is as high as $61 \mathrm{~kg}$ per year and $20 \mathrm{~kg}$ per capita per year in rural areas. Teff is, therefore, an economically superior good that is relatively more consumed by richer than by the poor. The lower consumption by the poor is also partly explained by the high prices of teff, which are typically twice as high as the cheapest cereal, i.e. maize (Minten et al., 2013). Teff has great potential as an industrial crop; however, processing teff grain into flour and injera is limited to a small number of urban processors. Teff is nutritionally rich while high in complex carbohydrates. Teff is gluten free and can easily be tolerated by patients suffering from celiac disease. Teff has also a high content of fiber, calcium, and iron which is important in preventing pregnancy anemia (Dekking and Koning, 2005).

Value chain is important in the enforcement of standards, with each player ensuring that the product originating from the previous stage adheres to the standards (UNECA, 2009). According to Fufa et al. (2011) teff value chain 
program supports the doubling of teff production and ensures farmers to access sufficient markets to capture the highest value from their production, increase incomes and reducing the price to consumers within five years.

Minten et al. (2013) studied teff value chain by selecting major teff producing zone in Ethiopia. The study showed that the adoption of modern farm inputs by farmer's increases, increasing willingness to pay for convenience in urban areas, improvement of foodservice industry, improved marketing efficiency, quality demands rise and shifts from the cheap red varieties to the more expensive white ones. According to this study, transformation happened in the last decade in the staple food value chain in Ethiopia, which contrasts the pervasive view that agricultural value chains in Africa are static and change slowly (Rakotoarisoa et al., 2011). Developing country food value chains are changing rapidly, fueled by the expansion of modern food retailers, wholesalers and manufacturers, which coexist and interact with firms in traditional food value chains. As a result, the structure of food value chains is being shaped in ways that have no precedent in developed countries, where the transition from traditional to primarily modern system occurred (Gómez and Ricketts, 2013).

Despite teff, trade is highly profitable; little is known about the farm level competitiveness of teff production, and the distribution of the costs and value-added between the chain participants, which include farmers, traders and processors. Although past studies in Ethiopia (Minten et al., 2013; Fufa et al., 2011) have looked at value chain analysis of teff, literature on quantitative value chain analysis that captures the cost build-ups along the chain is scarce. Becho and Dawo districts have major potential in production of teff. Land cultivated for teff production in Becho and Dawo was $85 \%$ and $80 \%$ of the land cultivated in the district respectively (Districts agriculture bureau, 2014). This study gives more emphasis on production and marketing segments of teff value chain and without mentioning of another actor, financing aspects and supportive services provided to all actors of teff value chain. The objective of the study is to identify the value chain actors, evaluate their roles and relationships in the value chain;

The Basics of Value Chains: Value chain is the full range of activities and services required to bring a product or service from its conception to sale in its final markets (MicroLINKS, 2012). A value chain, thus, encompasses the entire network of actors involved in input supply, production, processing, marketing and consumption. These value chain actors operate within an institutional environment, which can either facilitate or hinder its performance (Gereffi, 1995). Laws, rules, regulations, policies, international trade agreements, social norms and customs all contribute to this institutional environment, as do public goods such as infrastructure, research, extension, price information systems and business development services. Businesses that provide crosscutting services such as finance and transport likewise contribute key elements to the institutional environment affecting the value chain performance (Haggblade and Theriault, 2012).

The idea of value chains is quite intuitive. It exists when all of the actors in the chain operate in a way that maximizes the generation of value along the chain. Value chain can be in a narrow or in a broad sense. In the narrow sense, a value chain includes the range of activities performed within a firm to produce a certain output. In other words, all activities constitute the chain which links producers to consumers and each activity adds value to the final product. The broad approach does not only look at the activities implemented by a single enterprise. Rather, it includes all its backward and forward linkages, until the level in which the raw material is produced will be linked to the final consumers (Kaplisnky and Morris, 2002).

A useful methodology for understanding how markets operate, for a particular good, is value chain analysis. A value chain is a set of value-adding activities through which a product passes from the initial production or design stage to final delivery to the consumer and can be local, national, regional or international in scope (Kanji et al., 2005). ILO (2009) also defined value chain as a sequence of target-oriented combinations of production 
American Research Journal of Business and Management (ARJBM)

factors that create a marketable product or service from its conception to the final consumer.

Mapping the Value Chain: Value chain mapping is drawing a visual representation of the value chain system. Maps identify business operations, chain operators and their linkages, as well as the chain supporters within the value chain. Chain maps are the core of any value chain analysis and therefore indispensable. It serves both an analytical purpose and a communication purpose, as chain maps reduce the complexity of economic reality with its diverse functions, multiple stakeholders, interdependencies and relationships to a comprehensible visual model (GTZ, 2007).

The first step of a value chain analysis is called mapping. In order to do so, the boundaries to other chains need to be defined. The main idea is initial to identify the actors and then to 'map' the traced product flows within the chain, including input supply, production, processing, and marketing activities. The objective is to give an illustrative representation of the identified chain actors and the related product flows. A mapped value chain includes the actors, their relationships, and economic activities at each stage with the related physical and monetary flows (Faße et al., 2009). There are two different kinds of approaches used for mapping.

Functional and Institutional Analysis: Mapping is denoted as a functional and institutional analysis which starts with constructing a 'preliminary map' of a particular chain to provide an overview of all chain actors (institutional analysis) and the type of interaction between them (functional analysis). The results can be presented either in a table or flow chart, which is called the 'preliminary map' of the chain. The methodology includes three essential aspects for developing a preliminary map (Faße et al., 2009):

$>$ The principal functions of each stage

$>$ The agents carrying out these functions

The principal products in the chain and their various forms into which they are transformed along the entire chain

Once the flow chart has been drawn, these flows are quantified, both in physical and monetary terms. The procedure allows assessing the relative importance of the different stages or segments of the chain. This methodology was applied by Rudenko (2008) identifying and mapping the relevant value chain stages for the cotton and wheat value chain in Uzbekistan. Kaplinsky and Morris (2002) suggest similar procedures for implementing value chain analysis. Their concept consists of two steps in order to map the value chain. The first step includes drawing an 'initial map', which shows the chain boundaries including the main actors, activities, connections and some initial indicators of size and importance. The second step consists of elaborating the refined map by quantifying key variables such as value-added, and by identifying strategic and non-strategic activities.

Social Network Analysis: Another approach for mapping value chains is the social network analysis (SNA) originated in social sciences. Similar to the Faße et al. (2009) concept, it serves as a tool for mapping and analyzing relationships and flows between people, groups, and organizations. The initial flow chart of the chain consists of various nodes and links arranged in form of a matrix. The nodes represent the actors while the links describe the relationships and flows between the nodes. SNA is used when the value chain is more characterized by a network than a single vertical chain. SNA provides both visual and mathematical analysis of chain relationships, but it is still in the early stages to be used in value chain analysis. So far, only a few studies have applied this approach.

Clottey et al. (2007) used SNA to map the small livestock production system in Northern Ghana for a value network analysis. The objective was to analyze the introduction of animal health care services in the region. Thus, the value-creating linkages were mapped. Afterwards, SNA was employed to determine the pathways of

Volume 2016

Page 4 
value exchanges and individual relationships among the small farmers and enterprises. As a result, the authors found out that the input supply is weakly linked with the upstream livestock chain activities. In addition, the knowledge flow among farmers and actors from research and development (RandD) needed to be improved to strengthen the entire livestock production chain.

It is worthwhile to assess previous studies undertaken on teff value chains and other cereal crops but merely few studies were conducted in Ethiopia on different commodities. A study conducted on innovations in banana value chain in Metema (Kahsay et al., 2008) indicated that very limited sucker production and supply, low demand for locally available varieties, absence of improved varieties and limited knowledge of banana production in the area were some of the challenges for innovation in banana value chain to enhance its production and productivity. On the other hand, high market demand for improved banana varieties, production potential of the area, availability of irrigation water in the area, presence of enabling environment including policy support for irrigation agriculture, provision of technical advice from both government and nongovernmental organization to boost banana production and productivity in the area are also mentioned as opportunities for innovation in the value chain.

The major potato value chain actors include input (seed, fertilizer, fungicide, farm implement) suppliers, producers, wholesalers, brokers, retailers and consumers. There is no significant structural difference between the potato value chain in SNNPR and Tigray. The main difference is the quantity of potato marketed and associated prices at different levels and the level of value addition by the different market actors. The constraints of value chain include a lack of technical, business or financial support services, lack or a difficult regulatory framework, poor public infrastructure (roads, telecommunications, electricity, etc.), a lack of information about or weak connections to end markets, and/or inadequate coordination between firms. Costs of vegetable seeds vary significantly based on the source with imported varieties such as tomato and carrot being more expensive. In some instances, the price of seed potato seems lower than the price of ware potato, showing that farmers use inferior quality potato seed tuber (in terms of size, freedom from seed borne diseases and genetic degeneration because of viral infection) for seed (Emana and Nigussie, 2011).

According to Minten et.al (2013) teff value chain had divided in to upstream and downstream. The use of modern input such as herbicide, pesticide, improved seed varieties, chemical fertilizer increased productivity in upstream of teff value chain, however, broadcasting is common method used for teff sowing. The share of red teff in production declined from 36 percent of total production to 20 percent. The reasons for the decline of red teff produce over time. First, the prices for red teff are significantly low. Second, red teff traditionally used to have higher productivity than white teff; this is now changing as high-performing white varieties have recently become available. Thirdly, only very few improved red varieties are currently available.

\section{METHODOLOGY}

Description of Study Area: The study was conducted in two districts of south-west Shewa zone (Oromia region) namely, Becho and Dawo district. Becho and Dawo district are located at latitude/longitude of $8^{\circ} 35^{\prime} \mathrm{N}$ $38^{\circ} 15^{\prime} \mathrm{E}$ and $8^{\circ} 45^{\prime} \mathrm{N} 38^{\circ} 10^{\prime} \mathrm{E}$, and at about $80 \mathrm{~km}$ and $96 \mathrm{~km}$ from the capital Addis Ababa, respectively.

The livelihood of Becho and Dawo District is categorized as mixed farming and the main economic activities are crop production and livestock production. It has dominantly midland agroecology characteristics with a few highland areas. All wealth groups cultivate teff, wheat and chickpeas. The significant annual incomes for all wealth come from own crop sale, including the sale of teff, wheat, chickpeas and trees followed by livestock sale and self-employment.

Volume 2016 


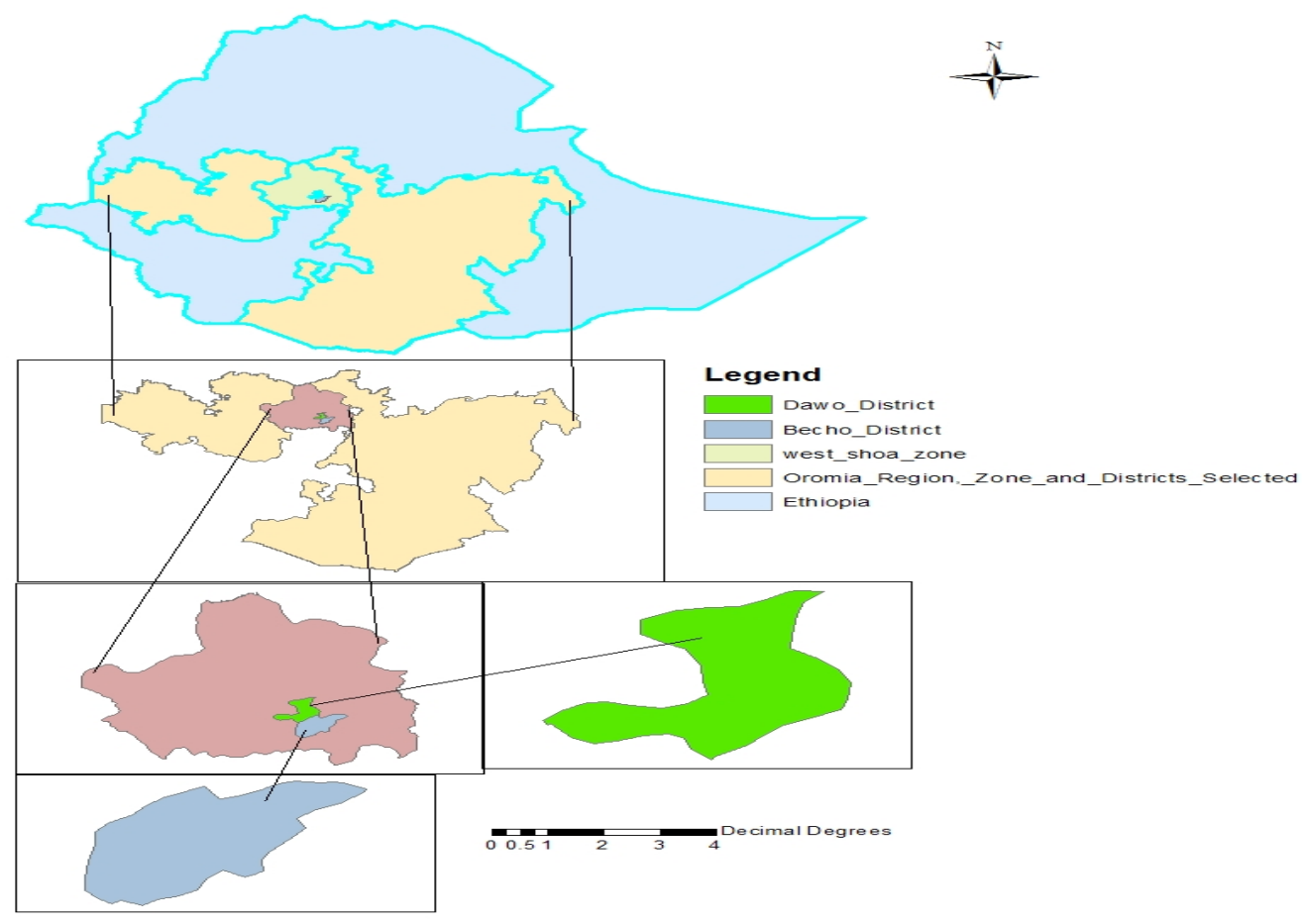

Figure1. Geographical location of the study area

\section{Source: Adapted from Ethiopia map}

Types and Sources Data: Both qualitative and quantitative types of data were collected from both primary and secondary data sources. The primary data type was collected from sample teff producers, cooperatives, NGOs, traders (wholesalers and retailers), processor (flour seller, hotel and Injera makers) and consumers by using structured questionnaires. The sampled teff farmers, cooperatives, NGOs, injera seller, flour seller, traders (wholesaler and retailers) were asked through direct interviewing. Secondary data on population size of the study areas, lists of Kebeles administration, list of licensed teff traders', amounts of production in the district, traders (wholesaler and retailer) and retail prices of teff, number of cooperatives and NGOs engaged in teff business was taken from Central Statistical Agency and trade and industry of the Districts. Apart from conducting individual interviews, key informant interviews and focus group discussion was held with farmers, traders, consumers, districts agriculture bureau manager, developments Agents (DAs) and representatives of kebeles farmers.

Methods of Sampling: The survey was carried out using a multi-stage sampling method, based on the selection of the combination of different sampling methods. First, within each district, the kebeles administration was ranked from smallest to the largest producer (in terms of farm size allocated to teff production in the district in 2014/15). Then kebeles administrations were stratified into two, less land cultivated for teff production (cultivating all together 50 percent of the areas in the district) and more land cultivated for teff production (cultivating all together 50 percent of the area). According to this stratification in Becho district seven kebeles administration was classified under more land cultivated and 12 kebeles was classified under less land cultivated. Following the same procedure for Dawo districts, six kebeles administration was classified under more land cultivated and 14 kebeles were under less land cultivated. Eight kebele administrations were randomly and proportionally selected from the two strata. One kebele administration was randomly and proportionally chosen from the more land cultivated by kebeles administration and three from the less land cultivated kebeles 
administration of each district randomly and proportionally. In the second stage, several teff producers sampled from each selected kebele were obtained proportionally. Finally, 150 sample households were interviewed from each sample kebele randomly and proportionately.

Sample size was determined using probability proportional to sample size-sampling technique Cochran's (1977).

no $=\frac{Z^{2 *}(P)(q)}{d^{2}}$

$n_{1}=\frac{n o}{(1+n o / N)}$

Where; $\mathrm{n}_{\mathrm{o}}=$ desired sample size when population greater than 10,000

$\mathrm{n}_{1}=$ finite population correction factors when population less than 10,000

$\mathrm{Z}=$ standard normal deviation (1.96 for $95 \%$ confidence level)

$\mathrm{P}=0.1$ (proportion of population to be included in sample i.e. 11\%) q =is 1-P i.e. (0.89),

$\mathrm{N}=$ is total number of population, $\mathrm{d}=$ is degree of accuracy desired $(0.05)$.

The total number of teff producers in the two districts was 20,025 farmers. The number of teff producers in Becho and Dawo districts was 11967 and 8058 respectively (Agriculture office of districts). Depending on the proportion of teff producing farmers in the two districts of selected kebeles the number of respondents from each district was 80 and 70 from Becho and Dawo districts respectively.

no $=\frac{Z^{2} *(P)(q)}{d^{2}}$

$n o=\frac{(1.96)^{2} *(0.11)(0.89)}{(0.05)^{2}}=\approx 150$

Table1. Distribution of sample households across districts and sample kebeles

\begin{tabular}{|l|l|l|l|l|}
\hline District & Kebeles & Number of households & Proportion & Sample households \\
\hline \multirow{4}{*}{ Becho } & Awash Bune & 1615 & 0.21 & 31 \\
\cline { 2 - 5 } & Jato & 965 & 0.12 & 18 \\
\cline { 2 - 5 } & Simbiro Ciracha & 958 & 0.12 & 19 \\
\cline { 2 - 5 } & Boji & 600 & 0.08 & 12 \\
\hline \multirow{5}{*}{ Dawo } & Neno Gabriel & 1298 & 0.17 & 25 \\
\cline { 2 - 5 } & Kersa Bombi & 929 & 0.12 & 18 \\
\cline { 2 - 5 } & Makit Suntare & 1047 & 0.13 & 20 \\
\cline { 2 - 5 } & Dawo Saden & 347 & 0.04 & 7 \\
\hline Total & & 7759 & 1.00 & 150 \\
\hline
\end{tabular}

Source: Agriculture Bureau of Becho and Dawo (Own computation)

According to information obtained from the districts trade office the total number of licensed teff traders in the two districts were 109 and 100 in Becho and Dawo districts respectively. The sample size was determined using Cochran's (1977) sampling formula. The sample size of traders in the two districts was 28 and 26 in Becho and Dawo districts respectively when allocated proportionally based on the number of traders. The other actors included in the sample of this study include; 10 consumers, 5 cooperatives, 2 union, 10 injera seller, 2 mill house and 2 flour seller.

Volume 2016 
American Research Journal of Business and Management (ARJBM)

\section{Method of Data Analysis}

Descriptive analysis: This method of data analysis refers to the use of percentages, means, chi-square, t-test and standard deviations. It was employed in the process of examining and describing marketing functions, farm household characteristics, role of intermediaries, marketing margin and value share of actors. Value chain map is a standard tool of a value chain research and analysis (ILO, 2009). It is used to identify and categorize the value chain actors, their roles, and relationships in the teff value chain of the study area.

Value-added: To compute the value-added all costs and sales for the various stages were measured as well as the underlying product and input prices. Actual market prices were used for financial analysis. Thus according to guides from GTZ (2007), the following were calculated;

Value Added (VA): It is the difference between the value of output of a product $i^{\text {th }}\left(Y_{i}\right)$ and the value of intermediate inputs $\left(\boldsymbol{I}_{\boldsymbol{i}}\right.$ ) used in the productive activities and represents the value-added by an individual actor $j$ during the accounting period. The intermediate inputs are those factors of production that are totally transformed or consumed during the accounting period and are not available for use during the next period.

$V A_{i j}=Y_{i j}-I_{i j}$

\section{Overall value-added}

The overall value-added was computed as;

$T V A_{\text {chain }}=\Sigma V A_{\text {agents }}$

\section{RESULTS AND DISCUSSION}

\section{Storage and Transportation Facility in Teff Value Chain}

The storage system is a farming activity used to store the product until price increase or input supply available to buy for the next farming season.

Table2. Types of storage and purpose of storing teff

\begin{tabular}{|c|c|c|c|c|c|c|}
\hline \multicolumn{2}{|l|}{ Variables } & \multicolumn{2}{|c|}{ Participants } & \multicolumn{2}{|c|}{ Non participants } & \multirow[b]{2}{*}{$\chi^{2}$} \\
\hline & & $\mathrm{N}$ & $\%$ & $\mathrm{~N}$ & $\%$ & \\
\hline \multirow[t]{3}{*}{ Storage material } & $\operatorname{Togogo}^{1}$ & 47 & 39.83 & 12 & 37.50 & \multirow[t]{3}{*}{0.266} \\
\hline & Gotera & 63 & 53.39 & 17 & 53.13 & \\
\hline & Plastic sack & 8 & 6.78 & 3 & 9.38 & \\
\hline \multirow{4}{*}{$\begin{array}{l}\text { Motive of storing the } \\
\text { product }\end{array}$} & Expecting high price & 39 & 33.05 & 10 & 31.25 & \multirow[t]{4}{*}{0.307} \\
\hline & Lack of demand & 6 & 5.08 & 1 & 3.13 & \\
\hline & Storing for saving & 29 & 24.58 & 8 & 25.00 & \\
\hline & For consumption & 44 & 37.29 & 13 & 40.63 & \\
\hline \multirow[t]{2}{*}{ Field to Homestead } & Donkey & 107 & 90.68 & 4 & 12.50 & \multirow[t]{2}{*}{0.282} \\
\hline & Animal cart & 11 & 9.32 & 28 & 87.50 & \\
\hline \multirow{4}{*}{$\begin{array}{l}\text { Home to Local } \\
\text { market }\end{array}$} & Animal cart & 33 & 27.97 & 11 & 34.38 & \multirow{4}{*}{1.06} \\
\hline & Handcart & 2 & 1.69 & 1 & 3.13 & \\
\hline & Human labor & 1 & 0.85 & 0 & 0.00 & \\
\hline & Donkey & 82 & 69.49 & 20 & 62.50 & \\
\hline
\end{tabular}

Source: Generated from field survey data (2014)

${ }^{1}$ It is material made of mud and used to store cereal crops products in the study areas 
About $39.83 \%$ of the sample market participants point out that they put their teff by filling in Togogo. Table 9 showed that $33.05 \%$ of the samples of market participant households store their products by expecting high price and $37.29 \%$ store their product for home consumption and the remaining was for saving and lack of demand. The means of transportation used by farmers were pack animal (most of the time donkey), animal cart and hand cart. The majority of the farmers used the donkey to transport the teff product from field to home stead; from home to local market and mill house in percent the number of farmer used donkey for transportation was $74 \%, 62 \%$ and $72 \%$ respectively for both market participant and non-participant farmers.

\section{Teff Value Chain Actors Roles and Linkages}

Chain actors are differing from chain supporters in terms of ownership status they have to the product. Chain actors own the product. Ownership is transferred from one actor to the next actor in the chain. Chain supporters supporting actors in the value chain in finance and providing other services but not own the product. The actors in teff value chain are input suppliers, farmers/producers, rural and urban retailers, rural/urban wholesalers, processors (flour sellers and injera sellers), NGO (Birmadu Folle), cooperatives/union, injera sellers and consumers. The teff value chain begins with input suppliers who supply production inputs to producers.

Specific roles played by each chain actors are discussed hereunder:

Supporting actors: They provide supportive services including training and extension, information, financial and research services. Cooperatives, micro finance, and NGOs are main supporting actors who play a central role in the provision of services. The actors need finances for different purposes. The farmers need finance to buy inputs of production, traders need finance to buy the product and some capital items like equipment and vehicles, processors need finance to buy products from traders and to buy capital items like machinery, vehicle etc., retailers need finance for working capital and warehousing. Microfinances and relatives provided financial service needed by the actor of teff value chain as depicted in Table below.

Input supplier: As revealed by sample farmers the input suppliers in teff value chain are farmers, cooperatives/ union and district agriculture bureau. The input provided includes seed, fertilizer, herbicides and pesticides. During the KII with district agriculture worker and DAs they said that sometimes there is a shortage of fertilizer and seed supply in Becho and Dawo district. The problem of teff production in the district was the unsuitable usage of seed and fertilizer by the farmers. This happens due to farmer's knowledge of how to use the fertilizer or lack of money to buy the amount of fertilizer that applied per hectare of land.

Table3. Percent of farmers getting services from various service providers

\begin{tabular}{|c|c|c|c|c|c|c|}
\hline \multirow{2}{*}{\multicolumn{2}{|c|}{ Variables }} & \multicolumn{4}{|l|}{ District } & \multirow[t]{3}{*}{$\chi_{\text {-value }}^{2}$} \\
\hline & & \multicolumn{2}{|l|}{ Becho } & \multicolumn{2}{|l|}{ Dawo } & \\
\hline & & Frequency & Percent & Frequency & Percent & \\
\hline \multirow[t]{3}{*}{ Sources of input } & Agricultural office & 5 & 6.25 & 2 & 2.86 & \multirow{3}{*}{4.35} \\
\hline & Cooperative/Union & 75 & 93.75 & 65 & 92.86 & \\
\hline & Market & 0 & 0.00 & 3 & 4.28 & \\
\hline \multirow{2}{*}{$\begin{array}{l}\text { Access to market } \\
\text { information }\end{array}$} & Yes & 65 & 81.25 & 53 & 75.71 & \multirow[t]{2}{*}{0.68} \\
\hline & No & 15 & 18.75 & 17 & 24.29 & \\
\hline \multirow{4}{*}{$\begin{array}{l}\text { Sources of market } \\
\text { information }\end{array}$} & From teff traders & 22 & 33.85 & 18 & 32.73 & \multirow[t]{4}{*}{$23.72^{* * *}$} \\
\hline & Radio & 17 & 26.15 & 12 & 21.82 & \\
\hline & Telephone & 3 & 4.62 & 11 & 20 & \\
\hline & Neighbor & 23 & 35.38 & 14 & 25.46 & \\
\hline \multirow[t]{2}{*}{ Sources of credit } & Microfinance & 53 & 96.36 & 52 & 94.54 & \multirow[t]{2}{*}{2.92} \\
\hline & Relative & 3 & 3.64 & 3 & 5.46 & \\
\hline
\end{tabular}

Volume 2016

Page 9 
American Research Journal of Business and Management (ARJBM)

\begin{tabular}{|c|c|c|c|c|c|c|}
\hline \multirow[t]{2}{*}{ Take training } & Yes & 64 & 80 & 57 & 81.43 & \multirow[t]{2}{*}{$11.74^{* *}$} \\
\hline & No & 16 & 20 & 13 & 18.57 & \\
\hline \multirow{4}{*}{$\begin{array}{l}\text { Service provided } \\
\text { by government }\end{array}$} & Excellent & 26 & 32.50 & 13 & 18.57 & \multirow[t]{4}{*}{$11.63^{* * *}$} \\
\hline & Very good & 25 & 31.25 & 13 & 18.57 & \\
\hline & Fair & 23 & 28.75 & 30 & 42.86 & \\
\hline & Unsatisfactory & 6 & 7.5 & 14 & 13.13 & \\
\hline \multirow{5}{*}{$\begin{array}{l}\text { Service provided } \\
\text { by NGOs }\end{array}$} & Excellent & 2 & 2.5 & 3 & 4.35 & \multirow[t]{5}{*}{$13.75^{* * *}$} \\
\hline & Very good & 12 & 15 & 1 & 1.45 & \\
\hline & Fair & 13 & 16.25 & 5 & 7.25 & \\
\hline & Unsatisfactory & 4 & 5 & 2 & 2.90 & \\
\hline & No service at all & 49 & 61.25 & 58 & 84.06 & \\
\hline
\end{tabular}

***, ** and * are statistically significant at 1\%, 5\% and 10\% probability level, respectively

Source: Generated from field survey data (2014)

The survey result show that about $92.86 \%, 2.86 \%$ and $4.28 \%$ sample farmers from Dawo district obtained farm input from cooperative/union, agricultural office and market respectively. When Becho and Dawo districts were compared based on access to market information there is a significant difference between the Becho and Dawo districts. The result showed that Becho district had better access to teff market information than Dawo district. Out of sampled farmers from Becho about $81.25 \%$ had access to market information and $75.71 \%$ of sampled farmers from Dawo district have access to market information. The survey result indicated that there are four sources of market information for farmers. About 33.85\%, 26.15\%, 4.62\% and 35.38\% of Becho district farmers obtained market information from traders, radio, telephone and neighbor respectively, while about $32.73 \%, 21.82 \%, 20 \%$ and $25.46 \%$ of Dawo district farmers obtained market information from traders, radio, telephone and neighbor respectively. The chi-square indicates that there was a significant differences between Becho and Dawo districts in respect of source of market information at 1\% probability level.

About $82 \%$ of the farmers took the training in 2013/14 farming season on use of input and technology of teff production and 18\% farmers did not take training in 2013/14 farming season. From sampled teff producers in Dawo district 71\% took the training in 2013/14 farming season for the use of input and technology of teff production (raw planting) and 29\% did not take training in 2013/14 farming season for the use of input and technology of teff farming. In terms of training for teff production, Becho district farmers were more accessible to training than Dawo district farmers it may due to Becho farmers were more access to service providing by government than Dawo district. There was a significant difference between Becho and Dawo district in terms of training on the teff production input use and technology in 2013/14.

The service provided to the farmer by the government was better in Becho district in which $32.50 \%$ of farmers were satisfied with the service provided by government than Dawo district in which $18.57 \%$ of farmers were satisfied. There was a significant difference between Becho and Dawo districts regarding the service provided by governments at the $1 \%$ level of significance. On the other hand, in Becho District around $61.25 \%$ of farmer reported that there was no service provided to them by NGO while in Dawo about $84.06 \%$ of the farmers reported that they were not getting any service from NGOs. This is due to the existence large number of a NGOs in Becho and the existence of a small number of a NGOs in Dawo district. There is a statistically significant difference between Becho and Dawo districts in terms of service provided by NGOs at 1\% probability level. Farmers who receive the credit had higher yields, income, and improved access to farm inputs compared to non-beneficiaries. Microfinance were the main providers of credit to the farmers about $96.36 \%$ and $94.54 \%$ farmers obtained credit service were provided for Becho and Dawo districts, while relatives provided the remaining credit service to the farmers.

Volume 2016

Page 10 
Functional and institutional analysis approach of a value chain mapping was used to identify the different actors involved in the teff value chain, and to understand their roles and linkages. The current value chain map of teff in Becho and Dawo district is depicted in Figure 3.

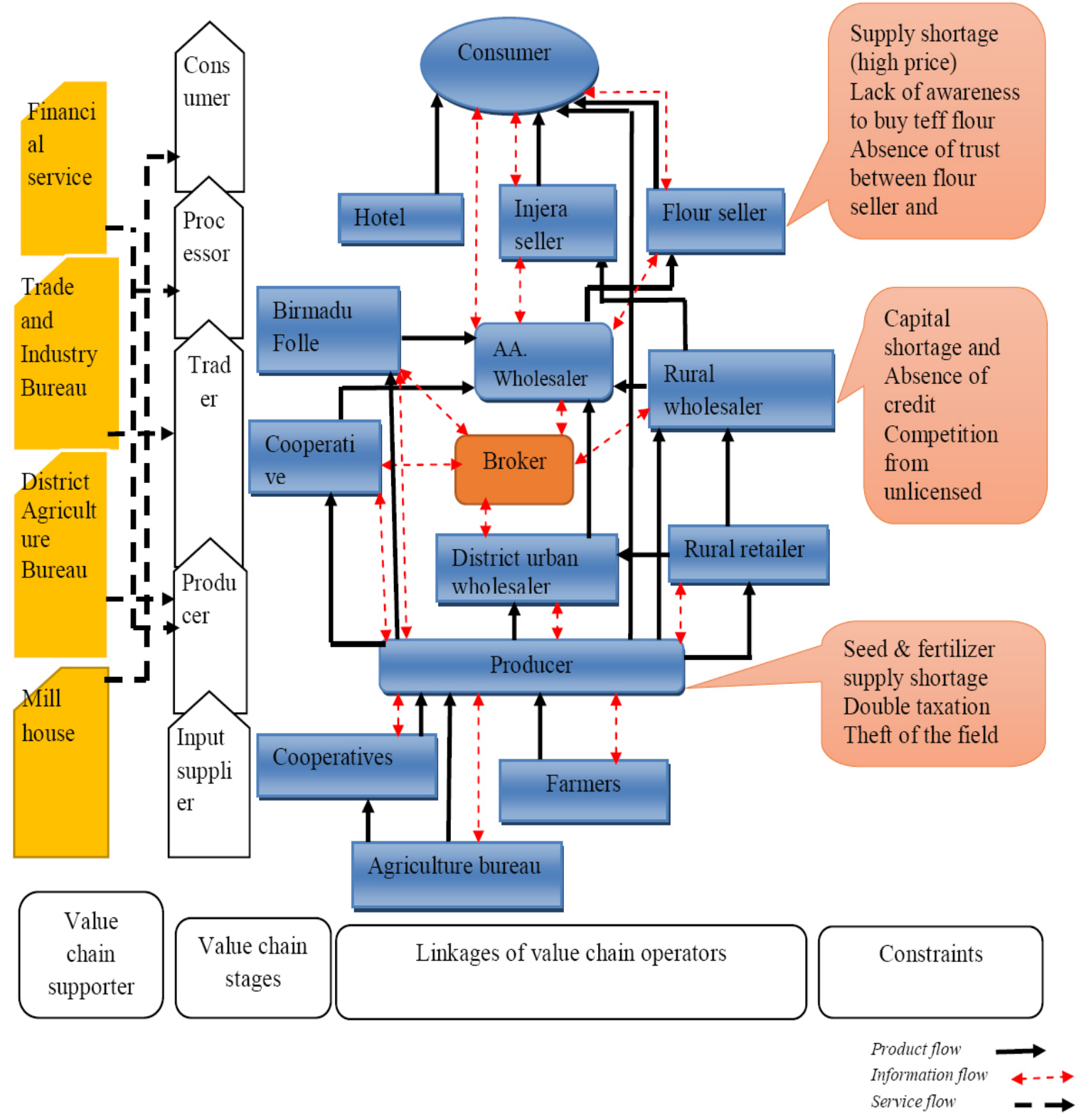

Figure3. Teff value chain map

Source: Own draw from data collected, 2014

Producers/Farmers: Teff producers are small-scale farmers who grow teff mainly for home consumption and increasingly for income through the marketing of surplus product. The seeds that are used are in most cases home saved seeds of local varieties and improved seed obtained from cooperatives/agriculture bureaus. After harvests, the teff is sold mainly to local traders such as retailers and wholesalers; they can also sell directly to local consumers. Farmers are a value chain actors that participate in both productions as well as the marketing of surplus commodities they produce. At the same time, they transport teff to the nearest markets or urban 
markets by themselves, either using a pack animal or animal driven carts. The amount sold to vary from the size of teff fields, the amount harvested and food requirement of household (quantities of cereals).

Rural retailer: These can be business-oriented farmers. To be a rural retailer, one needs to have a transportation facility like donkeys, working capital and price information. Rural retailers collect agricultural products from rural areas and supply to major markets. In addition, they will take back consumable items non-available in village markets like salt, kerosene, soap, sugar, coffee etc. in rural areas. The rural retailer role is to gather and bulk quantities of teff. Rural retailers are literate and are accustomed to visiting the nearby towns repeatedly. They go into the most remote areas to collect teff from farm gates, storage facilities or local trade centers. Once a teff is accumulated in a sufficient quantity, the rural retailers then sell the merchandise in the main trading town centers (Tulu bolo and Busa) to rural wholesaler and urban wholesalers. They use their financial resources and their local knowledge to buy teff from the surrounding area.

Brokers: Brokers are agents who bring together potential buyers and sellers. Most of the Addis Ababa's wholesalers have their own brokers. The function of these brokers is agitating district wholesalers to sell the produce to the wholesalers and sometimes these brokers observed forcing wholesalers/cooperatives to sell their produce to the wholesalers. They disseminate price, types of teff and other information to the market participants and they play the leading role in influencing teff trade and price formation in Addis Ababa Ehil Berenda market. These intermediaries play important role in the process of arbitrage on Tulu bolo and Busa markets, in particular for the two district urban and rural wholesalers, cooperatives and Birmadu Folle for selling the product to Addis Ababa market. They get their reward on quintal basis, which is about 5 birr per quintal. The brokers sometimes go beyond facilitation of transaction and tend to control and fix prices, create price symmetry and make extra benefits from the process in addition to convincing the district market wholesalers to sell their teff product at the prices set by Addis Ababa market wholesalers. Moreover, brokers are divided into village level brokers, urban brokers and commission agents.

Rural wholesalers and urban wholesalers: Wholesalers act as a link between the main producing centers and main regional or national markets. These traders collect teff from both farmers and rural retailers. Moreover, mixing up and packing takes place at this stage by rural and urban wholesalers. Teff grain is packed in hundred kilograms to transport it to the terminal market in Addis Ababa. These wholesalers need to have a working capital, weighing balance, canvas, negotiating skill in local language, knowledge of the different varieties of teff, price information, etc. These wholesalers facilitate transportation of teff produces to the terminal market by themselves. Districts wholesalers are major actor of the teff value chain who usually buy teff of larger volume than any other actors in the teff value chain and resell the products to the urban consumer and processors. Wholesalers usually buy from the farmers/rural retailers and bulk up large quantities to transport in Addis Ababa. Wholesalers in the terminal market directly sell teff produce to processors, institutions and consumers through brokers. These wholesalers are responsible to temporarily store and negotiate with purchasers until the produce is disposed. Rural wholesaler most of the time located outside the market or on the gate of the market where farmers come to the central market. Rural wholesalers have more access to farmers than urban wholesalers. Commodities bought from different sources put together in one place (store) to be categorized so that uniformity of the product attained.

Cooperatives: They are a farmer's organization created by farmers and providing services such as fertilizer, herbicides and pesticides to farmers during the farm season. In addition to providing such services, they buy teff from farmers at a fair price and after teff bought, they give a dividend to farmers. But in the study areas the activities they were performing were not satisfying farmers because they were not efficient enough in terms of timely provisions of agricultural input and buying of their harvested products.

Flour seller: These actors of teff value chain are located in Addis Ababa, which buy teff from wholesaler and mill the teff. After teff is changed to flour, they measure and pack the flour according to the demand of consumer 
and sell to hotels and restaurants, injera sellers or consumers. The problem encounters the flour sellers in an Addis Ababa market were people's awareness about consuming the packed teff flour. This is due to the absence of trust between flour sellers and consumers of teff. The consumer suspects that the flour sellers mixed teff flour with the other cereal flour.

Injera seller: Injera is a sourdough-risen flatbread with a unique, slightly spongy texture. Injera sellers were teff value chain actor existed in Tulu bolo, Busa and Addis Ababa. They buy the teff from different actors such as rural retailer/wholesaler, urban wholesaler or flour seller.

Birmadu Folle: Facilitator for Change is a national resident child-centered community development organization without religious, political or government affiliation. It was established in Ethiopia with the aim of facilitating the development process among disadvantaged grass-root communities to tackle the root cause problems behind child vulnerability. Birmadu Folle Project is parts of project designed by facilitator for change, which is operating in Dawo, Seden sodo and Becho district of South west Shewa zone on Women Capacity Enhancement program, Education and Skill Training and household food security and market promotion program components. The role of these NGOs is enhancing the capacity of women in the district through engaging them in the market. To be a member of group marketing they paid five birr monthly, after that, Birmadu Folle gives some money to buy teff from farmers located in the kebeles. They sold teff product to urban wholesaler and each member take dividend at the end of the year.

Consumer: Most of the consumers who were interviewed were earned income with an average monthly income of 500-3000ETB. They showed varied preferences for eating teff with only $42.5 \%$ saying they had preference to consume magna teff, $45 \%$ had preference to consume mixed teff and $7.5 \%$ did prefer to consume red teff, whereas $5 \%$ were indifferent between consumption of mixed and magna teff. On average, the rural dwellers consume 4.98 quintals per year. During the interview the consumer revealed that the problem of teff consumption was high price of product that about $75 \%$ of consumer said that the price of teff is the serious problems that exist in the study areas. Consumers buy teff from cereal market/wholesalers/farmers, take the teff home for cleaning, get the teff milled at the mill house, and then prepare the injera at home. Consumer incurs cost of milling teff that is paid to mill house due to service provided by a mill house.

\section{Gross Margin and Value Share of Teff Value Chain Actors}

Value added represents the contribution of payments to the primary factors of production such as seed, fertilizer and other inputs, the more value a teff farmers can add to a product for a given primary and intermediate cost configuration, the greater its profitability. The potential for farmers to add value to their produce lies in their ability to keep intermediate input costs as low as possible (GTZ,2007). To calculate the value added by each actor of teff value chain two channels is considered. The first channel is the channel through which the teff products reach the district consumer. The second channel considered for calculation of value added by each actor of teff value chain is the channel through which the teff products reach the Addis Ababa city teff consumer.

The intermediate cost incurred by farmers to produce a quintal of teff includes cost of input (seed, fertilizer and pesticide cost), harvesting, threshing and transport cost. The teff producing farmers in Becho district added a value of 455 birr per quintal, which is $33.58 \%$ of the total value added in the district. The Dawo district farmers adding a value of 404 birr per quintal that is $34.71 \%$ of the total value added in the district. Value added by teff farmers in Dawo district was greater than that of Becho district, this is due to the price paid and marketing cost difference between the two districts. The value added by a farmer was smaller than a value added by injera seller. The intermediate cost the farmer incurs was greater than intermediate cost incurred by injera seller. As indicated in Table 14 the share value added by farmers was higher at district market compared to Addis Ababa market. Results indicated that the presence of brokers in a value chain reduces the share of value added by 
American Research Journal of Business and Management (ARJBM)

farmers. Reddy et al. (2010) also concurs that shorter marketing chains present more benefits to farmers than longer ones. The higher benefits can be attributed to lower transaction and marketing costs.

The value adding activity performed by rural retailer was cleaning and packaging of teff as it is appropriate to sell to urban/rural wholesalers. Rural retailers added 235 birr per quintal in Becho district and the rural retailer add birr 180 per quintal in Dawo district. The percentage of a value added from the total value added is 17.34\% and 15.46\% for Becho and Dawo district respectively (Table 14).

Table4. Distribution of value added of teff across actors and district

\begin{tabular}{|c|c|c|c|c|c|c|}
\hline$\frac{\text { Becho }}{\text { Actors }}$ & $\begin{array}{l}\text { Sales } \\
\text { price }\end{array}$ & $\begin{array}{l}\text { Intermediate } \\
\text { inputs }\end{array}$ & $\begin{array}{l}\text { Value added by } \\
\text { actor at district }\end{array}$ & $\begin{array}{l}\text { Value added by } \\
\text { actor at AA }\end{array}$ & $\begin{array}{l}\% \text { share } \\
\text { of value } \\
\text { added }\end{array}$ & $\begin{array}{l}\% \text { share of } \\
\text { value added } \\
\text { at AA }\end{array}$ \\
\hline Producer & 1100 & 645 & 455 & 455 & 33.58 & 27.33 \\
\hline Rural retailer & 1350 & 1115 & 235 & 235 & 17.34 & 14.11 \\
\hline Rural wholesaler & 1450 & 1360 & 90 & 90 & 6.64 & 5.41 \\
\hline $\begin{array}{l}\text { District urban } \\
\text { wholesaler }\end{array}$ & 1570 & 1470 & 100 & 100 & 7.38 & 6.01 \\
\hline Injera seller * & 2075 & 1600 & 475 & & 35.06 & \\
\hline AA wholesaler & 1650 & 1600 & & 50 & & 3.00 \\
\hline Flour seller & 1860 & 1700 & & 160 & & 9.61 \\
\hline Injera seller & 2275 & 1700 & & 575 & & 34.53 \\
\hline \multicolumn{7}{|l|}{ Dawo } \\
\hline Producer & 1090 & 686 & 404 & 404 & 34.71 & 26.42 \\
\hline Rural retailer & 1300 & 1120 & 180 & 180 & 15.46 & 11.77 \\
\hline Rural wholesaler & 1420 & 1315 & 105 & 105 & 9.02 & 6.87 \\
\hline $\begin{array}{l}\text { District urban } \\
\text { wholesaler }\end{array}$ & 1500 & 1445 & 55 & 55 & 4.73 & 3.60 \\
\hline Injera seller* & 1950 & 1530 & 420 & & 36.08 & \\
\hline AA wholesaler & 1650 & 1600 & & 50 & & 3.27 \\
\hline Flour seller & 1860 & 1700 & & 160 & & 10.46 \\
\hline Injera seller & 2275 & 1700 & & 575 & & 37.61 \\
\hline
\end{tabular}

Note: * indicate the actor involved at the district only and AA represents Addis Ababa

Source: Generated from field survey data (2015)

The percentage share of value added by rural wholesaler and urban wholesaler in Becho district were 6.64 and 7.38 percent respectively. While in Dawo district the value share of rural and urban wholesaler was 9.02 percent and 4.73 percent respectively. The value adding activity undertaken by wholesaler is arranging the category of teff, cleaning, packaging and transportation of teff to scarce areas. The rural wholesaler added a value of 90 birr per quintal and urban wholesaler added a value of 100 birr per quintal in Becho district. The value added by Dawo district rural wholesaler is greater than Becho district rural wholesaler.

The intermediate costs averaged 1600 birr per quintal of teff for district injera sellers. One quintal of teff converted to 593 injera and average selling price of one injera was 3.50 birr. Then the sales price of one quintal of teff after converting to injera, was 2075 ETB for Becho district. Calculation of value added by the injera seller for Busa town and Addis Ababa city was done by the same procedure. Injera seller adds 475 birr per quintal, which is $35.06 \%$ of the total value added in Becho district for teff sold in Tulu bolo town. The percent share of 
total value added was $36.08 \%$ in Dawo district, which is about 420 birr per quintal for injera sold in Busa town. Tulu bolo town Injera seller took the highest percent of value shares of Becho district teff value chain actors.

Flour seller value chain actor only existed in the Addis Ababa market. Flour seller adds $9.61 \%$ and $10.46 \%$ of the total value added for teff supplied to Addis Ababa from Becho and Dawo districts respectively, which is about 160 birr per quintal for Becho and Dawo district teff. Value addition by Addis Ababa injera seller for teff supplied from Becho and Dawo district was 575 birr per quintal, which is about $34.53 \%$ and 37.61 of the total value added respectively. The injera seller added the highest value added at district and Addis Ababa. This implies that the value adding activity performed by injera seller is greater than other actor involved in the teff value chain.

\section{Value chain governance and operators linkages}

The forms of a chain governance range from spot market to vertical integration of the entire value chain. Analyzing the existing business linkages includes judging the intensity and sustainability of cooperation, the existence of lead firms and their attitude and commitment. A related point is the analysis of conflicts arising from differences in negotiation power, asymmetric information and competition for resources between value chain operators. Business linkage studies also include the degree of sector organization, especially the capacity of commercial business associations (GTZ, 2007).

Chains are characterized by a dominant party, known as the lead firm, which coordinates the interaction between the links in the chain and becomes responsible for upgrading activities in the individual links. The role of 'governance' can undertake either by buyer-driven chains or by producer-driven chains (Gereffi, 1995). In Becho district about $85 \%$ of the producers accepted the price and product specification determined by the buyer, even though the price was lower than the average market price. In the case of the Dawo, about 12.65\% of producers had to accept the price determined in negotiations with traders and the rest accept the price offered by the buyers. It appears that the producers in the study areas have limited bargaining power. This is due to the lack of a proper market information system, highly scattered production structure, lack of producers' organizations, and minimal bargaining power, smallholders' farmers are highly dependent on intermediaries to take their produce to the markets and forced to accept the price set by buyers. There is buying and selling (transaction) but little exchange of information and learning from one another (interaction) in teff value chain in both districts. This type of value chain governance is market-based relationships, because the conditions of exchanging goods and services are based on the market price. This means that buyers (traders) govern teff value chain in study area.

Table5. Price determination of teff product

\begin{tabular}{|c|c|c|c|c|}
\hline \multirow{2}{*}{\multicolumn{2}{|c|}{ Variables }} & \multicolumn{2}{|l|}{ Districts } & \multirow[t]{2}{*}{ Chi-square } \\
\hline & & Becho (\%) & Dawo & \\
\hline \multirow[t]{3}{*}{ Price setting } & Buyers & 85 & 83.33 & \multirow{3}{*}{$8.92^{* * *}$} \\
\hline & $\begin{array}{l}\text { Set by demand and } \\
\text { supply }\end{array}$ & 7.50 & 0.00 & \\
\hline & Negotiations & 7.50 & 12.65 & \\
\hline \multirow{3}{*}{$\begin{array}{ll}\text { Quality of } \\
\text { information }\end{array}$} & Wrong information & 23.08 & 38.46 & \multirow{3}{*}{$7.98^{* *}$} \\
\hline & Medium information & 66.15 & 61.54 & \\
\hline & Adequate information & 10.77 & 0.00 & \\
\hline \multicolumn{2}{|c|}{ Farmers linkage with buyers (yes) } & 2.50 & 5.71 & 1.00 \\
\hline \multicolumn{2}{|c|}{ Farmers linkage with other farmers (yes) } & 12.50 & 15.71 & 0.32 \\
\hline
\end{tabular}

Volume 2016

Page 15 
American Research Journal of Business and Management (ARJBM)

\begin{tabular}{|c|c|c|c|c|}
\hline \multicolumn{2}{|l|}{ Member to cooperatives (yes) } & 93.75 & 95.57 & 0.59 \\
\hline \multicolumn{2}{|c|}{ Difficulty of getting buyer by farmers (yes) } & 53.75 & 72.46 & $5.53^{* *}$ \\
\hline \multirow{4}{*}{$\begin{array}{l}\text { Place to put the product if } \\
\text { buyer not exist }\end{array}$} & Take back to home & 19.23 & 24.07 & \multirow{4}{*}{$10^{* *}$} \\
\hline & Sold at other market & 23.07 & 14.815 & \\
\hline & Sold at low price & 44.23 & 33.335 & \\
\hline & Put at relative house & 13.46 & 27.78 & \\
\hline \multirow[t]{3}{*}{ Farmers level of buyer trust } & Very little & 18.75 & 22.86 & \multirow[t]{3}{*}{0.39} \\
\hline & Little & 68.75 & 65.71 & \\
\hline & Moderate & 12.50 & 11.43 & \\
\hline
\end{tabular}

***, ** and $*$ are statistically significant at 1\%, 5\% and 10\% probability level, respectively

Source: Generated from field survey data (2015)

Improving flow of information between farmers and potential buyers is crucial in reducing transaction costs within the value chain because it lowers the cost of searching for information. Monitoring costs is reduced if information regarding buyers, sellers, and other market conditions such as price transmission and product quality is effectively relayed between various chain participants. Information asymmetry affects the coordination of the value chain actors. Based on the quality of information transmitted from buyers/other sources about the price of teff to supplier there was a problem in which only $10.77 \%$ and $0 \%$ farmers obtained adequate information on the price of teff in Becho and Dawo districts. The survey result indicates that the farmers took the teff product to market based on information obtained from different sources. About $53.75 \%$ and $72.46 \%$ of Becho and Dawo district farmers faced difficulty of getting teff product to buyers and forced to sell their product to low price, otherwise put relative house and transfer the product to other market in which the farmers incur additional transportation cost. There was significant difference between Becho and Dawo district in terms of difficulty to get a buyer when they supplied teff product to the market due to an asymmetric information flow between teff producers and buyers.

When the transaction (mainly buying and selling) takes place between enterprises at different stages of the value chain it is called vertical linkages. The farmers' linkages with buyers of his teff product are vertical linkages. However, the survey result showed that only $2.50 \%$ and $5.71 \%$ of the farmers had linkages with their teff product buyers from Becho and Dawo district respectively. Horizontal business linkages refer to the transactions between enterprises operating in the same functional segment of the value chain. These are, for example, joint purchase and sales activities and joint use of equipment and facilities. The teff farmers' linkages with other teff farmers showed that there is only $12.50 \%$ and $15.71 \%$ of Becho and Dawo district farmers linked to obtain the market players and transfer farming experience in the study area. This implies that there were weak linkages among the teff producers in the study areas.

Table 15 indicates that $93.75 \%$ of the farmers belong to cooperatives from Becho district and $95.57 \%$ of the farmers were member of cooperatives from Dawo district. During the FGD farmers mentioned various reasons of being members of the cooperatives to get fertilizers, pesticides and other services because it is a requirement by the Agriculture bureau or cooperatives. A trust index based on a household's rating of their level of confidence in buyer was scaled on a 1 (very little) - 5(very much) point scale. Information was found to flow from buyers, through their agents and/or brokers, to the farmers. Out of the total sample from Becho district $18.75 \%$, $68.75 \%$ and $12.50 \%$ of the farmer level of their buyers trust were very little, little and moderate respectively. In Dawo district about $22.86 \%, 65.71 \%$ and $11.43 \%$ of the farmer level of their buyer trust were very little, little and moderate respectively. This implies that on average majority of the farmer didn't have the trust on their buyers. 
The teff value chains in the study areas are characterized by a highly fragmented. The majority of study areas value chain actors have very little direct contact with producers of teff. The disadvantages of fragmented form of teff value chain in Becho and Dawo districts were;

$>$ There was no guarantee for the quality of the teff supplied, because there was very little feedback from the wholesaler or processors to their suppliers and contracts didn't exist to enforce certain quality standards.

$>$ It was impossible to trace the supplied teff products. In the light of increasing demand for teff consumption, this situation is a big drawback in Becho and Dawo district.

$>$ Disintegrated value chains were accompanied by high search costs, since most of the actors were not embedded in the chains. In other words, since wholesalers or processors didn't have strong relationships with their suppliers and purchasers, they have had to look for the suppliers being able to deliver the right quality and quantity.

$>$ Knowledge transfer was reduced because chain specific channels were missing. Knowledge about quality standards, prices, and market trends couldn't reach the upper ends of the chains or farmers.

\section{Value chain upgrading}

Upgrading refers to the acquisition of technological capabilities and market linkages that enable firms to improve their competitiveness and move into higher-value activities (Kaplinksy and Morris, 2002). Process, product and functional upgrading can enhance the value chain productivity and competitiveness. Upgrading entails not only improvements in products, but also investments in people, knowledge, processes, equipment and favorable work conditions. In Becho and Dawo district some of the sampled producers engaged in product and process upgrading activities. Table 16 presents a summary of the changes or improvements made to the product. These changes were defined as a new variety grown and use of fertilizer to increase production. More than half of the producers (52.5\%) changed the type of seed used for production of teff. The use of improved seed and fertilizer by smallholder producers may be considered as product and process upgrading which introduces new products and increasing efficiency of internal process for production.

Table6. Upgrading value chain activity performed by producers of teff

\begin{tabular}{|c|c|c|c|c|c|c|}
\hline \multirow{2}{*}{\multicolumn{2}{|c|}{ Variables }} & \multicolumn{4}{|c|}{ District } & \\
\hline & & \multicolumn{2}{|c|}{ Becho } & \multicolumn{2}{|c|}{ Dawo } & \\
\hline & & $\mathrm{N}$ & $\%$ & $\mathrm{~N}$ & $\%$ & \\
\hline \multirow[t]{3}{*}{ Type of seed used } & Improved & 42 & 52.50 & 42 & 60.00 & \multirow{3}{*}{$6.37^{*}$} \\
\hline & Local & 34 & 42.50 & 20 & 28.57 & \\
\hline & Both & 4 & 5.00 & 8 & 11.43 & \\
\hline \multirow[t]{2}{*}{ Product differentiation } & Yes & 65 & 81.25 & 56 & 80.00 & \multirow[t]{2}{*}{0.037} \\
\hline & No & 15 & 18.75 & 14 & 20.00 & \\
\hline \multirow[t]{3}{*}{ Way product differentiation } & Colour & 31 & 47.69 & 35 & 62.50 & \multirow[t]{3}{*}{2.96} \\
\hline & $\begin{array}{l}\text { Purity of product from } \\
\text { sand and other materials }\end{array}$ & 31 & 47.69 & 20 & 35.71 & \\
\hline & Mixing with other crops & 3 & 4.62 & 1 & 1.79 & \\
\hline
\end{tabular}

$* * *, * *$ and $*$ are statistically significant at $1 \%, 5 \%$ and $10 \%$ probability level, respectively

Source: Generated from field survey data (2014) 


\section{Challenges of Value Chain Actors}

\section{Production and marketing constraints of teff producers}

The marketing problem that market participant farmers face includes absence of infrastructure, storage facility, farmer reluctance to sell, double taxation, price setting and others are depicted in Table 17. Out of the market participants farmers $9.32 \%$ had the problem of double taxation and $83.05 \%$ had price-setting problem.

From the total non-participant's farmers $6.25 \%$, faced the problem of double taxation and $80.67 \%$ faced price setting problem. In terms of the marketing problem such as double taxation and price setting there was no significant difference between market participants and non-participants. The production problem that encountered market participants and non-participants are shortage of fertilizer, seed supply and land and the sudden occurrence of diseases. There was no significant difference between market participants and nonparticipants, farmers in terms of shortage of fertilizer, seed supply, and land availability, the sudden occurrence of diseases and theft on the field.

Table7. Production and marketing problems of farmers by market participation

\begin{tabular}{|l|l|l|l|l|}
\hline \multirow{2}{*}{ Variable } & \multicolumn{3}{|c|}{ Mean/proportion } & \multirow{2}{*}{$\mathrm{t}$ - $\chi^{2}$-value } \\
\cline { 2 - 5 } & Total & Participants & Non-participants & \\
\hline Shortage of fertilizer supply (yes) & 20.67 & 18.64 & 28.13 & 1.38 \\
\hline Shortage of seed supply(yes) & 39.33 & 38.14 & 43.75 & 0.33 \\
\hline Shortage of cultivable land(yes) & 27.33 & 27.12 & 28.13 & 0.01 \\
\hline Occurrence of disease(yes) & 18.67 & 16.95 & 25 & 1.08 \\
\hline Theft of the field(yes) & 24.67 & 25.42 & 21.88 & 0.17 \\
\hline Double taxation (yes) & 8.67 & 9.32 & 6.25 & 0.30 \\
\hline Price setting(yes) & 80.67 & 83.05 & 80.67 & 2.02 \\
\hline
\end{tabular}

Source: Generated from field survey data (2014)

During the FGD and KII with farmers, DAs and Agriculture bureau workers the following issues were raised as a problem that encountered teff producers in the study area;

High price of fertilizer: The price of fertilizer was very high which difficult to buy and reduce the amount of production. Despite existence of input suppliers, the high prices made it difficult for farmers to have access to fertilizer.

Poor access to extension services: In spite of the availability of extension services in the districts, their staffs did not work during the summer season when it is a critical time to help farmers professionally. On the other hand, they concentrated on the production aspect with giving less emphasis on marketing aspect and handling of products.

Poor market orientation of farmers: Farmers used to sell their crop immediately after harvest without seeking to make the best possible profit (at the best time or the best price) this was due to liquidity constraints.

Farmers have a strong mistrust towards buyers: Farmers thought traders, especially local traders, had cheated them through the use of fake weights and measurements.

Poor capacity of cooperatives: Cooperatives had low in capacity to bulk, process, add value, and sell together. Even though some cooperatives acquired stores, but they underutilized them.

High marketing costs: Due to the poor conditions of roads and the lack of access to means of transportation, it was costly and time-consuming for farmers to market their produce. For example, teff producing farmers in Dawo got it expensive to bring teff to Busa for sale.

Volume 2016

Page 18 
American Research Journal of Business and Management (ARJBM)

\section{Marketing Constraints of Traders}

The major marketing constraints that encountered traders were absence of infrastructure, absence of government support, double taxation, and absence of the storage facility, capital shortage, access to credit, farmer reluctance to sell and lack of demand. There was no problem of double taxation in Dawo district, but in Becho district from the total sample traders 19.43 percent reported that there was a problem of double taxation in the district. In terms of double taxation, there was a significant difference between Becho and Dawo districts. The absence of infrastructure was the problem in both districts. Out of the total sample traders 78 percent of traders reported that there was a problem of infrastructure in the district.

Table8. Marketing problems of traders

\begin{tabular}{|l|l|l|l|l|}
\hline \multirow{2}{*}{ Variable } & \multicolumn{2}{l|}{ Mean/proportion } & \multirow{2}{*}{${ }^{2}$-value } \\
\cline { 2 - 4 } & Total & Becho & Dawo & $\chi^{\text {-val }}$ \\
\hline Double taxation (yes) & 9.8 & 19.23 & 0.00 & $5.33^{* *}$ \\
\hline Absence infrastructure (yes) & 78 & 82.14 & 68.18 & 1.38 \\
\hline Absence of storage facility (yes) & 63.83 & 60.87 & 66.67 & 0.17 \\
\hline Information flow problem (yes) & 11.11 & 7.14 & 15.38 & 0.92 \\
\hline Capital shortage (yes) & 64.81 & 78.57 & 50 & $4.16^{* *}$ \\
\hline Access to credit (yes) & 9.26 & 10.71 & 7.69 & 0.15 \\
\hline Absence of government support (yes) & 75.93 & 71.43 & 80.77 & 0.64 \\
\hline Lack of demand (yes) & 3.70 & 7.14 & 0 & 1.66 \\
\hline Farmer reluctance to sell (yes) & 88.68 & 92.59 & 84.62 & 0.84 \\
\hline
\end{tabular}

** is statistically significant at $5 \%$ probability level, respectively

Source: Generated from field survey data (2014)

The problems that faced urban wholesaler, rural wholesaler, rural and urban retailer were absence of infrastructure, government support, and storage facility and farmer reluctance to sell their teff product. Especially during the survey, traders said that the government organized the farmers in the form of cooperatives to buy the teff product and reduced the amount supplied to the traders.

Table9. Problem of teff value chain actors in Becho and Dawo districts

\begin{tabular}{|c|c|c|c|c|c|c|c|c|c|}
\hline \multirow[t]{3}{*}{ Variables } & \multicolumn{8}{|c|}{ Value chain actors } & \multirow{3}{*}{$\begin{array}{l}\chi 2- \\
\text { value }\end{array}$} \\
\hline & \multicolumn{2}{|c|}{$\begin{array}{l}\text { Urban } \\
\text { Wholesaler }\end{array}$} & \multicolumn{2}{|c|}{$\begin{array}{l}\text { Rural } \\
\text { retailer }\end{array}$} & \multicolumn{2}{|c|}{$\begin{array}{l}\text { Urban } \\
\text { retailer }\end{array}$} & \multicolumn{2}{|c|}{$\begin{array}{l}\text { Rural } \\
\text { wholesaler }\end{array}$} & \\
\hline & $\mathrm{N}$ & $\%$ & $\mathrm{~N}$ & $\%$ & $\mathrm{~N}$ & $\%$ & $\mathrm{~N}$ & $\%$ & \\
\hline Double taxation (yes) & 4 & 11.76 & 1 & 12.50 & 0 & 0.00 & 0 & 0.00 & 1.19 \\
\hline Absence infrastructure (yes) & 27 & 79.41 & 5 & 71.43 & 4 & & 3 & 60.00 & 2.29 \\
\hline Absence of storage facility (yes) & 19 & 61.29 & 5 & 71.43 & 3 & 75.00 & 3 & 60.00 & 0.51 \\
\hline Information flow problem (yes) & 3 & 8.57 & 2 & 25.00 & 0 & 0.00 & 1 & 14.29 & 2.36 \\
\hline Capital shortage (yes) & 24 & 68.57 & 6 & 75.00 & 1 & 25.00 & 4 & 57.14 & 3.54 \\
\hline Access to credit (yes) & 3 & 8.57 & 1 & 12.50 & 1 & 25.00 & 0 & 0.00 & 2.01 \\
\hline Government support (yes) & 27 & 77.14 & 6 & 75.00 & 2 & 50.00 & 6 & 85.71 & 2.89 \\
\hline Lack of demand (yes) & 1 & 2.86 & 1 & 12.50 & 0 & 0.00 & 0 & 0.00 & 2.23 \\
\hline Farmer reluctance to sell (yes) & 30 & 88.24 & 7 & 87.50 & 3 & 75.00 & 7 & 100.00 & 1.66 \\
\hline
\end{tabular}

***, ** and * are statistically significant at 1\%, 5\% and 10\% probability level, respectively

Source: Generated from field survey data (2014) 
Capital shortage was the problem that encountered urban and rural retailer. When the problems were checked across different actors of the value chain, there was no significant difference between the actors. In addition to interviewing of traders KII was held with different supporters of teff value chains such as DAs, agriculture and trade and industry bureaus of the districts they said that there is mistrust among the different actors of the value chain due to each actor run to cheat other actors. The flow of product did not take into consideration the existence of demand for the product at that time, traders may decrease the price of the product, and farmer's reluctance to sell the teff happened.

\section{CONCLUSION AND RECOMMENDATION}

Teff is the most important crop in Ethiopia in terms of area and value of production, and is the second most important cash crop after coffee. Value chain actors of teff value chain in the districts were input supplier, farmers, rural retailer, rural wholesaler, urban wholesaler, urban retailer, cooperatives/union, injera seller, flour seller, NGOs (Birmadu Folle) and consumer. The supporter of value chain actors includes financial institution (microfinance), district agriculture office and cooperatives (union). The input suppliers in the teff value chain of Becho and Dawo districts were the district agriculture bureau and cooperative (Union) and they supply the input to farmers. During the production, farmers obtain services such as the amount of fertilizer, seed and herbicides used per hectare from the district agriculture bureau through DAs. After production, the farmers sell the product to rural retailer, rural wholesaler, urban wholesaler and cooperatives (union) and passing through this linkage the product reach the end consumer. The value share of producers, rural retailers, rural wholesalers, district urban wholesalers and district injera sellers in the teff value chain for Becho districts were $33.58 \%, 17.34 \%, 6.64 \%, 7.34 \%$ and $35.06 \%$ respectively. While for Dawo districts the value share from the total value added were $34.71 \%, 15.46 \%, 9.06 \%, 4.73 \%$ and $36.08 \%$ for producers, rural retailers, rural wholesalers, district urban wholesalers and district injera sellers in the teff value chain for Dawo district teff.

The production and marketing constraints that encounter farmers were shortage of fertilizer, seed supply, price setting, double taxation, theft on the field, the high price of fertilizer, poor access to extension services; farmers has a strong mistrust towards buyers, poor capacity of cooperatives, high marketing costs and the sudden occurrence of disease. Traders of teff in the district has the problem of double taxation, absence of infrastructure, capital shortage, access to credit, farmer reluctance to sell, information flow, lack of demand, absence of storage facility and the absence of government support. Among those problems that traders faced were double taxation and capital shortage are statistically significant difference between market participant and non-participant teff farmers. The upgrading activity performed by teff producers in the study areas are use of improved seed and fertilizer. Price determination and product specification in the teff value chain are governed by traders.

The following recommendation forwarded from the result obtained; Strengthening market linkages between farmers and consumers through provision of market information and promote collective marketing. This is due to information is crucial to strengthen the bargaining power of farmers, and to help them make the right decisions when it comes to selling their product (at the right time and the right price). Farmers have access to better markets information and better prices when they work in group. Markets should be regulated to reduce exploitation of farmers by potential buyers by making teff traders to obey the rules and regulations of Ethiopia commodity exchange and Oromia agriculture product marketing institutions. A pricing mechanism that takes cognizance of the production cost by smallholders should be adopted to avoid using prices that only favor upstream traders.

The value addition activity performed by different types of traders engaged in teff was cleaning and packing of teff. However, the price they charged to sell to the consumers was around double, which affect the consumers of teff in urban areas. The districts administrations bureaus and cooperatives (unions) should intervene trader's activity by organizing the urban teff consumers in cooperatives.

Volume 2016

Page 20 
Even though there was a standard set for teff price determination, traders were not guided by these standards. To solve this problem the Ethiopia commodity exchange, Oromia agriculture product marketing office, district agriculture office and unions must increase the capacity of cooperatives to reduce the price determination of traders and increasing the bargaining power of farmers.

\section{REFERENCES}

Abayneh, Y. (2013). Factors influencing market participation decision and extent of participation of haricot bean farmers in Meskan District, Ethiopia. International Journal of agricultural Economics, pp.17-26.

Abbot, J. C. and Makeham, J.P. (1981). Agricultural Economics and Marketing in the Tropics. Wing Tai Cheung Printing Co. Ltd, Rome. pp. 58.

Acharya, S. S., Chand, P. R., Birthal, S. K. and Negi, D. S. (2012). Market Integration and Price Transmission in India: A Case of Rice and Wheat with Special Reference to the World Food Crisis of 2007/08. Rome: Food and Agriculture Organization.

Aklilu, H. A. (2007). Village poultry in Ethiopia: socio-technical analysis and learning with farmers (Doctoral dissertation, PhD. Thesis, Presented to the Wagningen University, Wagningen, the Netherlands).

Arega, D. A., Manyong, V. M., Omanya, G., Mignouna, H. D., Bokanga, M. and Odhiambo, G. D. (2008, November). Smallholder marketed surplus and input use under transactions costs: maize supply and fertilizer demand in Kenya. In 2007 Second International Conference, August 20-22, 2007, Accra, Ghana (No. 52074).

Branson, R. E. and Norvell, N. (1983). Introduction of Agricultural Marketing, McGraw Hill Book Company, New York. 365p.

Central statistical agency (2007). Population and housing census of Ethiopia.

Central statistical agency (2013). Agricultural sample survey 2012 / 2013 Volume I report on area and production of major crops.

Clottey, V. A., Gyasi, K. O., Yeboah, R. N., Addo-Kwafo, A. and Avornyo, F. (2007). The small ruminant production system in Northern Ghana: a value network analysis. Livestock Research for Rural Development, 19(167).

Cochran, W. G. (1977). Sampling Techniques, $2^{\text {nd }}$ Ed.,New York: John Wiley and Sons, Inc.

Cramer, G. L. and Jensen, W. (1982). Agricultural Economics and Agribusiness, $2^{\text {nd }}$ Edition. McGraw Hill Book Company, USA. 222p.

Dekking, L.S. and Koning, K.F. (2005).The Ethiopian Cereal Teff in Celiac Disease. The New England Journal of Medicine 353;16.

Dereje, B. (2007). Assessment of Forest Coffee Value Chains in Ethiopia: a Case Study in Kefa Zone, Gimbo District. Msc Thesis Presented to University of Bonn 85p.

District agriculture bureaus (2014). Agricultural survey of Becho and Dawo districts amount of production teff and land under cultivation for farming season of 2013/14.

Dow, W. and E. Norton (2003) “Choosing Between and Interpreting the Heckit and Two-Part Models for Corner Solutions," Health Services and Outcome Research Methodology

Ehui, S., Benin, S. and Paulos, Z. (2009). Expanding Market Participation among Smallholder Livestock Producers. A Collection of Studies Employing Gibbs Sampling and Data from Ethiopian Highlands.

Emana, B. and Nigussie, M. (2011). Potato value chain analysis and development in Ethiopia. The case of Tigray and SNNP regions. Consultancy report. International Potato Centre (CIP) and USAID (United States Agency for International Development), Addis Ababa. 
Faße, A., Grote, U. and Winter, E. (2009). Value chain analysis methodologies in the context of environment and trade research (No. 429). Discussion papers//School of Economics and Management of the Hanover Leibniz University.

Feller, A., Shunk, D. and Callarman, T. (2006). Value Chain versus Supply Chain. Discussion Paper on Concepts of the Value Chain and the Supply Chain in a more Comprehensive and Integrative Manner, March 2006, BP Trends.

Fufa, B., Behute, B., Simons, R. and Berhe, T. (2011). Strengthening the Teff Value Chain in Ethiopia.

Gereffi, G. (1995). “Global Production Systems and Third World Development.” in: B. Stallings (ed.), Global Change, Regional Response: The New International Context of Development, New York, Cambridge University Press, pp.100-142.

Gereffi, G., Humphrey, J. and Sturgeon, T. (2005). The Governance of Global Value Chains. Review of International Political Economy, 12(1): 78-104

German Agency for Technical Cooperation (GTZ) (2007). Value Links Manual. The Methodology of Value Chain Promotion. Eschborn, Germany, 2007, GTZ.

Gilbert, C.L. (2006). Value Chain Analysis and Market Mower in Commodity Processing with Application to the Cocoa and Coffee Sectors. Presentation Paper for the FAO Workshop on Governance, Coordination and Distribution along Commodity Value Chains. April, 2006, Rome, Italy, FAO.

Gómez, M.I. and Ricketts, K.D. (2013). Food value chain transformations in developing countries Selected hypotheses on nutritional implications ESA Working Paper No. 13-05. , (13).

Haggblade, S. and Theriault, V. (2012). A Conceptual Framework for Promoting Inclusive Agricultural Value Chains by Table of Contents, (November), 0-37.

Haile, M., Tesfaye, A., Aregu, L. and Mulat, E. (2004). Market access versus productivity: The case of Teff by Market access versus productivity : the case of Teff, (April).

Hailu, T. and Seifu, K. (2001). "Production and importance of teff in Ethiopian Agriculture". Proceedings of the 'International workshop on Teff Genetics and Improvement' Debre Zeit, Ethiopia. 16-19 October 2000.

Holloway, G., Charles Nicholson, C. and Delgado, C. (1999). Agro-industrialization through Institutional Innovation: Transactions Costs, Cooperatives and Milk-Market Development in the Ethiopian Highlands. Mssd Discussion Paper No. 35

Humphrey, J. and Memedovic, O. (2006). Global Value Chains in the Agri-Food Sector, working paper on behalf of the UNIDO Strategic Research and Economics Branch, Vienna, Austria.

Iddo K., Ayal, K. and veleman, Z. (2006). Farm output, non-farm income and commercialization in rural Georgia, The electronic Journal of Agricultural and development Economics, Food and Agriculture Organization of the United States.Vol.3 (2): pages 276-286.

International Labor Organization (ILO) (2009). Local Value Chain Development for Decent Work. A Guide for Development Practitioners, Government and Private Sector Initiatives. Geneva, Switzerland, 2009, International Labor Organization.

Jagwe, J. (2010). Transaction costs and smallholder farmers' participation in banana markets in the Great Lakes Region of Burundi, Rwanda and the Democratic Republic of Congo. African Journal of Agricultural Research. , 6(1).

Kabeto, A. J. (2014). An analysis of factors influencing participation of smallholder farmers in red bean marketing in Halaba special district, Ethiopia (Doctoral dissertation, University of Nairobi). 
Kahsay, B., Puskur, R., Worku, T., D. Hoekstra, F. and Azage T. (2008). Innovation in Banana Value Chain Development in Metema District, Northwestern Ethiopia: IPMS Experiences. Paper presented at the international Conference on "Banana and Plantain in Africa: Harnessing International Partnerships to Increase Research Impact”, Kenya, Mombassa.

Kanji, N., MacGregor, J. and Tacoli, C. (2005). Understanding Market-based Livelihoods in a Globalizing World:Combining Approaches and Methods. London, England, International Institute for Environment and Development.

Kaplinsky, R. and Morris, M. (2002). A Handbook for Value Chain Research.Ottawa, Canada, International Development Research Center.

Kassa, B. (2010). Rice value chain in Metema district, north Gondar, Ethiopia: challenges and opportunities for innovation Addis Ababa University College of development studies.

Kenea, Y., Getachew, A. and Workneh, N. (2001). Farming Research on Teff: Small Holders Production Practices. In: Hailu Tefera, Getachew Belay and M. Sorrels (eds.). Narrowing the Rift: Tef Research and Development. Ethiopian Agricultural Research Organization (EARO).Addis Ababa, Ethiopia, pp.9-23.

Kim, S. and Shin, E. H. (2002). A longitudinal analysis of globalization and regionalization in international trade: A social network approach. Social Forces,81(2), 445-468.

Kohl, R.L. and Uhl, J.N. (2002). Marketing of Agricultural Product, $5^{\text {th }}$ Edition, Collier Macmillan, USA. 624p.

Kuma, B., Getnet, K., Baker, D. and Belay K.B. (2011). Determinants of participation decisions and level of participation in farm level milk value addition: The case of smallholder dairy farmers in Ethiopia. Ethiopian Journal of Applied Science and Technology, (2), pp.19-30.

Lambert, D. K., Lim, S. H., Tweeten, K., Leistritz, F. L., Wilson, W. W., Mckee, G. J. and Saxowsky, D. M. (2006). Agricultural Value Added: Prospects for North Dakota. Department of Agribusiness and Applied Economics, North Dakota State University.

Lewis, T. C., Wade, B., Kim, B., Anderson, B. and Emilio,T. (2008). Gender difference in Participation of smallholder farmers in the Northern Province of South Africa.

Maingi, G. (2006). Promoting agricultural value chains, 62-64.

Makhura, T. (2001). Ph.D dissertation on overcoming transaction costs barriers to market marketing styles. Journal of Agricultural Economics. Vol. 38: page 1-7.

Mamo, T., Tefera, T. and Byre, N. (2014). Factors influencing urban and peri-urban dairy producers ' participation in milk value addition and volume of milk value added in Welmera Woreda, West Shewa Zone of Oromia Regional State, Ethiopia. International Journal of livestock production. Pp.165-172.

Martínez-Espiñeira, R. (2006) “A Box-Cox Double-Hurdle Model of Wildlife Valuation: The Citizen’s Perspective," Ecological Economics, 58:1 (192-208).

Mather, D., Boughton, D. and Jayne, T.S. (2013). Explaining smallholder maize marketing in southern and eastern Africa: The roles of market access, technology and household resource endowments. Food Policy, 43, pp.248-266.

Mayer, F. and Gary, G. (2010). "Regulation and Economic Globalization: Prospects and Limits of Private Governance." Business and Politics, 12(3): 11.

Meijer, P.W.M. (1994).The Function of Maize Market in Benin, Bert Broundjin, Benin. 11-32p.

Volume 2016

Page 23 
American Research Journal of Business and Management (ARJBM)

Mendoza, G. (1995). A Premier on Marketing Channels and Margins. Analytical Methods. Price Analysis. 257-75.

MicroLINKS Wiki. (2012).Value Chain Approach. Accessed online at http://apps.develebridge.net/amap/index. php/Value_Chain_Approach on April 18, 2012

Minten, B. and Reardon, T. (2008). Food prices, quality, and quality's pricing in supermarkets versus traditional markets in developing countries. Applied Economic Perspectives and Policy, 30(3), 480-490.

Minten, B., Tamru, S., Engida, E. and Kuma, T. (2013). Using evidence in unraveling food supply chains in Ethiopia: The supply chain of teff from major production areas to Addis Ababa. Ethiopia Strategy Support Program-2 Working Paper, 54.

Monitoring African Food and Agricultural Policies, (2013). Analysis of incentives and disincentives for teff in Ethiopia draft version January 2013.

Mulat, D., Fantu G. and Tadele F. (2006). Agricultural Development and Food Security in Sub-Saharan Africa (SSA), Building the Case for More Public Support, the Ethiopian Case Study, FAO, Rome 2006

Mussema, R. (2006). Analysis of red pepper marketing: the case of Alaba and Siltie in SNNPRS of Ethiopia.

Myint, U. (2003). Agricultural Marketing Information System in Myanmar. Journal of publishing co.plc. New Delhi

Olwande, J. and Mathenge, M. (2012).Market Participation among Poor Rural Households in Kenya Market Participation among Poor Rural Households in Kenya. International Journal of agricultural Economics, pp.18-24.

Omiti, J.M. and Mccullough, E. (2009). Factors influencing the intensity of market participation by smallholder farmers : A case study of rural and peri-urban areas of Kenya. Agricultural Economics, 3(1), pp.57-82.

Piccinin, D. (2002). More about Ethiopian food : Teff. , pp.1996-1999.

Porter, M. and Miller, V.E. (1985). How Information Gives You Competitive Advantage. Harvard Pretoria. June, 2001. Publishing Company, New York, USA.

Rakotoarisoa, M., Iafrata, M. and Paschali. M. (2011). Why has Africa become net food importer? Explaining Africa's agricultural and food trade deficit. Rome: Food and Agriculture Organization of the United Nations.

Reardon, T. and Timmer. C.P. (2007). "Transformation of Markets for Agricultural Output in Developing Countries since 1950: How Has Thinking Changed?" In Handbook of Agricultural Economics. Vol.3, edited by R. E. Evenson and P. Pingali, 2808-2855. Amsterdam: Elsevier Press.

Reardon, T., Chen, K., Minten, B. and Adriano, L. (2012). The Quiet Revolution in Staple Food Value Chains. Enter the Dragon, the Elephant, and the Tiger. Mandaluyong City, Philippines: Asian Development Bank (ADB); International Food Policy Research Institute (IFPRI).

Renkow, M., Hallstrom, D.G. and Karanja, D. (2004). Rural infrastructure, transactions costs and market participation in Kenya. Journal of Development Economics 85 (5), 1140-1146.

Royer, J.S. (1995). “Potential for Cooperative Involvement in Vertical Coordination and Value-Added Activities.” Agribusiness 11(5).

Rudenko, I. (2008). Value Chains for Rural and regional Development: The Case of Cotton, Wheat, Fruit and Vegetable Value Chains in the Lower Reaches of the Amu Darya River, Uzbekistan. Dissertation, University of Hanover.

Volume 2016

Page 24 
American Research Journal of Business and Management (ARJBM)

Schere, F.M. (1980). Industrial Market Structure and Economic Performance. $2^{\text {nd }}$ Edition. Rand McNally College Publishing Agency, USA. 342p.

Scott, J. (1995). Price Products, and People Analyzing Agricultural Markets in Developing Countries, Lynne Rinner Publisher, and London. 498p.

Shilpi, Forhad and Umali-Deininger, Dina, (2007). Where to sell? Market facilities and agricultural marketing. Policy research working paper series 4455, The World Bank.

Singh, V. and Rai, K.N. (1998). Economics of production and marketing of buffalo milk in Harayana. Indian J. of Agric. Economics. 53(1): 43-52.

Siziba, S. and Diagne, A. (2011). Determinants of cereal market participation by sub-Saharan Africa smallholder farmer. , 2(1), pp.180-193.

Stephens, E. and Barrett, C. (2011). Incomplete credit markets and commodity marketing behaviour. Journal of Agricultural Economics 62 (1), 1-24.

Storck, H., Emana, B., Adnew, B., Borowiccki, A. and W/Hawariat, S, (1991). Farming Systems and resource economics in the tropics: Farming system and farm management practices of smallholders in the Hararghe Highland. Volume-II, Wissenschaftsverlag Vauk, Kiel, Germany.

Tshiunza, M., Lemchi, J. and Tenkouano, A. (2001). Determinants of Market Production of Cooking Banana in Nigeria. African Crop Science Journal 9. (3), pp. 537-547.

United Nations Economic Commission for Africa (UNECA) (2009). Developing African Agriculture through Regional Value Chains. Chapter 5. pp. 143-182. Economic Report on Africa. July, 2009, United Nations Economic Commission for Africa.

United Nations Industrial Development Organization (UNIDO) (2011). Agro-value chain analysis and development. Vienna, Austria.

Van Rensburg, A. (2006).Moving up the Value Chain. pp 1161-1170. Report on Enabling Business Process Outsourcing with Business Fractals. Pretoria, South Africa, 2006, EUROMA International Conference.

Vavilov, N.I. (1951). The Origin, Variation, Immunity and Breeding of Cultivated Plants. Roland Press, New York, (Translated from the Russian by K. Starrchester).

Wolday, A. (1994) and (1998). Food Grain Marketing Development in Ethiopia after Reform 1990, A Case Study of Alaba Siraro, The PhD Dissertation Presented to Verlag Koster University. Berlin 293p.

World Vision Ethiopia, (2009). Analysis of the Mango Value Chain from Homosha Assosa to Addis Ababa. pp 1-16. September 2008, Addis Ababa Ethiopia.

Citation: Efa Gobena Tura ${ }^{a^{*}}$, Dr. Degye Goshu", Tinsae Demisiec, Tadesse Kenead, "Analysis of Teff Value Chain in Bacho and Dawo Districts of South West Shewa, Ethiopia". American Research Journal of Business and Management, Volume 2016; pp:1-25

Copyright (C) 2016 Efa Gobena Tura ${ }^{{ }^{*}}$, Dr. Degye Goshu ${ }^{\mathrm{b}}$ Tinsae Demisie $^{\mathrm{c}}$, Tadesse Kenead, This is an open access article distributed under the Creative Commons Attribution License, which permits unrestricted use, distribution, and reproduction in any medium, provided the original work is properly cited. 